\title{
Erratum to: Expression of serum miR-200a, miR-200b and miR-200c as candidate biomarkers in epithelial ovarian cancer and their association with clinicopathological features
}

\author{
M. Zuberi ${ }^{1}$ - R. Mir ${ }^{2}$ - J. Das ${ }^{1}$ - I. Ahmad Ah. Javid $^{1}$ • P. Yadav ${ }^{1}$.

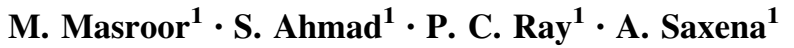

Published online: 5 August 2015

(C) Federación de Sociedades Españolas de Oncología (FESEO) 2015

\section{Erratum to: Clin Transl Oncol \\ DOI 10.1007/s12094-015-1303-1}

In the published article the name of the author R. Mir is not given correct. The correct name is: R. Mir.

The online version of the original article can be found under doi:10.1007/s12094-015-1303-1.

\footnotetext{
A. Saxena

alpanasaxena@hotmail.com

1 Department of Biochemistry, Maulana Azad Medical College, New Delhi 110002, India

2 Prince Fahd Bin Sultan Research Chair, University of Tabuk, Tabuk 71491, Saudi Arabia
} 